Szabó Mátyás

\title{
A KIHÁGÁS INTÉZMÉNYE AZ 1852. ÉVI OSZTRÁK BÜNTETÖ TÖRVÉNYKÖNYVBEN ${ }^{1}$
}

The Legal Institute of Transgressions in the Austrian Penal Code of 1852

Szabó Mátyás tanársegéd, Nemzeti Közszolgálati Egyetem Államtudományi és Nemzetközi Tanulmányok Kar, Állam- és Jogtörténeti Tanszék, szabo.matyas@uni-nke.hu

E tanulmány az 1879:XL. törvénycikk elfogadásának 140. évfordulója kapcsán a kihágás intézményének a nagy európai büntetőkódexek közül az 1852. évi osztrák Strafgesetzben történt szabályozásának rövid bemutatására vállalkozik. A kutatás során a magyar koronatartomány kormányzóságának (Katonai- és Polgári Kormányzóság), az osztrák Birodalmi Tanács szervezöbizottságának (Organisierungskommission des Reichsrats), illetve Anton Hye hagyatékának feldolgozására került sor. A tanulmányban a kódex kidolgozását, szerkezetét és legalapvetöbb jellemzöi mellett magyarországi bevezetésének körülményeit vizsgálom.

KulcsszavaK:

büntetőjog, kodifikáció, kihágási jog, államreformok, Habsburg Birodalom, neoabszolutizmus

This study aims to present a concise introduction about the institution of transgressions in the Austrian Penal Code of 1852, related to the $140^{\text {th }}$ anniversary of Act XL of 1879 . The archival research was based on the records of the Military and Civil Governorship of the Kingdom of Hungary, the Commission of Organisation of the Imperial Council of Austria (Organisierungskommission des Reichsrats) and the heritage of Austrian codificator Anton Hye. In this study the process of the codification, the structure and main specifics of the Code are going to be observed, as the circumstances and effects of its adoption in Hungary.

KEYWORDS:

criminal law, codification, transgression, state reforms, Habsburg Empire, neoabsolutism

\footnotetext{
Az Innovációs és Technológiai Minisztérium ÚNKP-19-3-I-NKE-128 kódszámú Új Nemzeti Kiválóság Programjának szakmai támogatásával készült.
} 


\section{BEVEZETÉS}

Az 1879. évi XL. törvénycikk elfogadásának jeles évfordulója méltó alkalomnak bizonyult a Csemegi-kódex és az európai büntetőjogi kódexek áttekintésére. A 2019. novemberi konferencia alkalmával arra jutottunk, hogy a kihágás intézményének az ausztriai büntető törvénykönyv alapján történő külön ismertetése nem csak azért indokolt, mert az osztrák jogrendszer az európai jogtörténet megkerülhetetlen részét képezi. Az 1852. május 27-én kiadott Büntető törvénykönyv a bűntettről, vétségről és kihágásról számunkra azon okból is kiemelt figyelmet érdemel, mert a kódexet 1852. szeptember 1-jei hatállyal Magyarországon is bevezették, így a magyar bíróságok gyakorlatában kötelezően és elsődlegesen alkalmazandó joganyaggá vált egészen 1861. június 23-ig, amikor az Országbírói Értekezleten (OBÉ) megalkotott Ideiglenes Törvénykezési Szabályok (ITSZ) az 1848 előtti állapotokat állította vissza. ${ }^{2}$

Az OBÉ-től a Csemegi-kódex elfogadásáig tartó átmeneti időszakban (1861-1878) a büntető törvénykezési gyakorlat legjelentősebb támpontja az ITSZ mellett Pauler Tivadar több kiadást megélt Büntetójogtana ${ }^{3}$ volt. Pauler munkái arról tanúskodnak, hogy az osztrák büntetőjog hatása a gyakorlatban 1861 után is tapasztalható volt. Az osztrák büntető törvénykönyv (OBTK) bár hivatalosan 1861-ig volt hatályban Magyarországon, ${ }^{4}$ az 1861 es Országbírói Értekezleten a büntetőkodifikáció megoldatlan maradt, így a bíróságok Pauler Tivadar Büntetöjogtanát (de facto büntető törvénykönyvként) alkalmazták, ${ }^{5}$ amely a korábban hatályban lévő osztrák büntetőkódexet a gyakorlatban fennmaradtként írja le. ${ }^{6}$

Az 1852. évi osztrák büntető törvénykönyv trichotómikus rendszere (amelyröl később részletesebben is szót ejtünk) a későbbi Csemegi-kódextöl szerkezetében némileg eltért. Hiszen míg az osztrák megoldásban az egységes büntető törvénykönyv I. része a bűntetteket (Verbrechen) tartalmazta, addig a II. része a vétségeket és kihágásokat (Vergehen und Übertretungen) együttesen tárgyalta. Ezzel szemben a magyar kodifikációs folyamatok során büntető törvénykönyv a büntettekről és vétségekről (1878. évi V. tc.), illetve külön a kihágásokról (1879. évi XL. tc.) készült. Finkey Ferenc az 1870-es évek magyar kodifikációs munkálataiban az 1870-es osztrák javaslat hatását is felfedezni véli. ${ }^{7}$ Mezey Barna

2 Ráth György (szerk.): Az országbírói értekezlet a törvénykezés tárgyában. Pest, Landerer és Heckenast, 1861.; Ideiglenes Törvénykezési Szabályok. Pest, Landerer és Heckenast, 1861.; Degré Alajos: A magyar büntetőjoggyakorlat általános jellemzése (1861-1867). Jogász szövetségi értekezések II. Budapest, 1979. 15.

Pauler Tivadar: Büntetőjogtan. Pest, Pfeiffer Ferdinánd, 1864-1865. I-II. k.

4 Az Ideiglenes Törvénykezési Szabályok nem terjedtek ki Erdélyre és Horvátországra, így ezeken a területeken az osztrák büntető törvénykönyv továbbra is hatályban maradt. Lásd: Veress Emőd (szerk.): Erdély jogtörténete. Kolozsvár, Forum Iuris, 2018. 318.; Heka László: Horvát alkotmány-és jogtörténet. II. rész (1848-tól 1918-ig). Szeged, JATE Press, 2004. 224.

Máthé Gábor: A kihágás intézménye I. Állam és Igazgatás, 30. (1980a), 8. 673-683. 680.

Képessy Imre: Az osztrák büntetőjog hatása a magyar büntetőjogi kodifikációra. In Fazekas Marianna (szerk.): Jogi Tanulmányok 2018. Budapest, ELTE Állam- és Jogtudományi Kar Állam- és Jogtudományi Doktori Iskola, 2018. 260-270. 262.

Finkey Ferenc: A magyar büntetöjog tankönyve. Budapest, Grill Károly, 1914. 84. 
ugyanezen osztrák javaslatot a Csemegi-kódex egyik elsődleges forrásaként nevezi meg, hozzátéve, hogy a vezérfonalat az 1871. évi német Strafgesetz nyújtotta. ${ }^{8}$

Az 1852. évi osztrák büntetőjogi reformot is vezető Anton Hye 1863. évi tervezete már egy, a büntettekről és vétségekről szóló törvénykönyvet tartalmazott, míg a rendőrségi kihágásokról (Polizeistrafgesetz) szóló javaslat 1870-re készült el. ${ }^{9}$ Azonban e két (talán a sors fintorának is tekinthetően a magyar kodifikációra ható) plánum - hasonlóan Julius Glaser (1874), Prasak (1881), Schönborn (1889-1891), Hugo Hoegel (1905) által kidolgozott javaslatokhoz, valamint Klein, Lammasch, Gleispach, Lenz és Schober (1909) tervezetéhez ${ }^{10}$ - sem emelkedett törvényerőre, így lényegében az 1852. évi törvény rendszere maradt tartós.

E tanulmányban tehát egyrészt a nagy európai büntetőjogi rendszerek és kódexek felelevenítéséhez csatlakozva, másrészt az 1870-es évek magyar büntetőjogi kodifikáció történeti előzményeihez adalékként szolgálva igyekszem bemutatni az 1852. évi osztrák Strafgesetz megalkotásának és bevezetésének folyamatát és dilemmáit, a kódex szerkezetét, a kihágás intézményének ${ }^{11}$ benne foglalt koncepcióját, illetve a közigazgatás és igazságszolgáltatás szétválasztásához, valamint a neoabszolutizmus államreformjaihoz való egyes kapcsolódási pontjait.

\section{AZ OBTK LÉTREJÖTTE}

Az 1852. évi osztrák büntető törvénykönyv bevezetése elválaszthatatlan volt az olmützi alkotmány (Märzverfassung) ${ }^{12}$ nyomán megindult birodalmi reformoktól. Az Ausztria újjáalakításaként (Neugestaltung Österreich) ismert államszervező munkálatok célja az egységes és oszthatatlan Osztrák Császárság megteremtése, az összmonarchia (Gesamtmonarchie) centralizált intézményrendszerének, birodalmi elvek (Reichsidee) mentén történő felépítése, a jogharmonizáció megvalósítása az örökös tartományok, illetve a ciszlajtán és transzlajtán területek között.

A monarchia egységállama kialakításának tervét a szilveszteri pátens (1851. december 31.) tette véglegessé. A pátenshez csatolt, Schwarzenberg miniszterelnökhöz intézett legfelsőbb kézirat tartalmazta az államszervezés alapelveit, amelyben Ferenc József az osztrák büntetőtörvény egész birodalomban történő bevezetéséről is rendelkezett. ${ }^{13}$

\footnotetext{
8 Mezey Barna: „A föltétlen igazság és a társadalom fenntartásának érdeke”. Az első magyar büntetőtörvénykönyv. In Horváth Attila (szerk.): Tanulmányok a Csemegi-kódex megalkotásának 140. évfordulója tiszteletére. Budapest, Dialóg Campus, 2020. 44.

9 AVA Nachlässe AN Hye 10.10.

10 Finkey (1914) i. m. 71.

11 A kihágás anyagi intézményéről részletesen lásd: Máthé (1980a) i. m.; Máthé Gábor: A kihágás intézménye II. Állam és Igazgatás, 30. (1980b), 9. 804-818.

12 Edmund Bernatzik: Die österreichischen Verfassungsgesetze mit Erläuterungen. Wien, Manzsche k. u. k. HofVerlags und Universitäts-Buchhandlung, 1911. 246-266.

13 Uo. 215.
} 
A birodalmi kormányzat a bécsi egyetem büntetőjogász és észjogtan professzorát, Anton Hye-t bízta meg a büntetőjogi reformmunkálatokkal, aki az igazságügyi kormányzatban és kodifikátorként is maradandót alkotott. ${ }^{14}$

Anton Hye teljes mértékben megfelelt a kor jogász-kodifikátor karakterének. Több mint négy évtized szövevényes joganyagát kellett egységes rendszerbe szerveznie, olyan módon, hogy a saját humánus meggyőződése és a korszerü megoldások mellett a jogpolitikai megfontolások, a szilveszteri pátens rendelkezései, valamint a Birodalmi Tanács (Reichsrat) és a Minisztertanács (Ministerrat) kívánalmai is teljesüljenek.

Hye elöször Sommaruga igazságügy-minisztertől még a politikai büncselekményekre vonatkozó módosítás megalkotására kapott felhívást 1848 augusztusában, majd Alexander Bach 1849-ben igazságügy-miniszterként egy teljesen új, egységes kódex mellett foglalt állást. Anton Schmerling miniszter 1850-ben bizottságot állított fel a munkálatokra, egyúttal az örökös tartományokban bevezették az új osztrák büntető perrendtartást, az 1803. évi büntető törvénykönyv alaki részét hatályon kívül helyezve. Hye 1850-ben és 1851-ben is benyújtott egy-egy javaslatot, ez utóbbit az év folyamán a Birodalmi Tanács és a Minisztertanács hosszasan tárgyalta, aminek következtében Ferenc József egy közös bizottságot (gemischtes Minister- und Reichsrath-Comité) volt kénytelen felállítani. ${ }^{15}$ A bizottság munkája nyomán Hye kénytelen volt a tervezetet a szilveszteri pátensben megfogalmazott államszervezési elvekhez is hozzáigazítani, a büntető törvénykönyv így végül csak 1852. szeptember 1-jén lépett hatályba.

A jogalkotónak az európai büntetőjogbeli széles körü tájékozottsága, jogtörténeti és a birodalmi kormánylap szerkesztésében szerzett tapasztalata és levéltári gyakorlata mellett - hagyatékából és jegyzeteiből - technokrata attitüdje és hatalmas munkabírása is kitűnik. Munkamódszerét vizsgálva: az 1863. évi javaslat készítése során mind a jogellenes magatartásokról, mind a büntetésekről, mind az alapelvekről és alakzatokról táblázatos rendszerbe foglalt összesítések és jegyzetek is fennmaradtak. Hye az egyes tényállásokról külön-külön táblázatba szedett összehasonlítást készített a különböző európai kódexekkel. ${ }^{16} \mathrm{Az}$ általános részhez tartozó összehasonlításban 16 európai büntetőtörvény

14 Anton Ritter Hye-Glunek 1849-ben nyert rendes minisztertanácsosi állást a cs. kir. Igazságügyi Minisztériumban, egyúttal a Birodalmi Kormánylap Intézetének elöljárójává is kinevezést kapott. 1857-től a minisztérium jogalkotásért felelős osztályának vezetője, 1865-től titkos tanácsos és a börtönügy főfelügyelője, az 1867 es évben igazságügy-miniszter, majd 1869-től az Urak Házának (Herrenhaus) örökös tagja, illetve a Birodalmi Törvényszék állandó referense. Az 1849. évi sajtórendtartás, az 1852. évi büntető törvénykönyv, az 1853 . évi büntetőeljárási törvény, a közjegyzőségröl szóló törvény, illetve számos tervezet és vitaanyag kidolgozása füződik Hye nevéhez, amelyet számos kitüntetéssel ismertek el. Lásd: Österreichisches Biographisches Lexikon 1815-1950, Bd. 3. Bécs, VÖAW, 1961. 22.

15 Olechowski, Thomas:ZurEntstehung desösterreichischen Strafgesetzes 1852. In Thomas Olechowski-Chirstian Neschwara - Alina Lengauer (szerk.): Grundlagen der österreichischen Rechtskultur. Festschrift für Werner Ogris zum 75. Geburtstag. Böhlau, Wien, 2010. 326-336. 
és javaslat, míg a különös részhez készített táblázatokban az 1852. évi osztrák kódex mellett 19 európai büntetőtörvény és javaslat szerepel. ${ }^{17}$

Az 1852. évi büntető törvénykönyv kommentárjában Anton Hye kifejti a munkálatok során felmerült dilemmát egy teljesen újonnan megalkotandó joganyag fogadtatásáról és alkalmazásának nehézségeiről. ${ }^{18}$ Bár a kodifikáció szempontjából egyszerűbbnek tartotta volna egy teljesen új büntetö törvénykönyv megalkotását, 1851-52-ben végül mégis az 1803. évi büntetőtörvény módosítására, javítására és kiegészítésére került sor.

A döntésben jelentős szerepet játszott az udvari hatóságok (Hofstellen) és a különböző tartományok hatóságainak (Landesstellen) jogalkotó tevékenysége is, amely éppen a kihágások rendszerét kezdte inkonzisztenssé tenni. Hye kiemelte, hogy a kódex az 1803 óta alkotott szabályokra épül, és mélyen gyökerezik az elmúlt évtizedek „hazai” (ausztriai) bírósági gyakorlatában. Egyúttal túlzott optimizmussal remélte - az Ausztriának a Magyarországgal közös fejedelem alatti több évszázados léte okán - a revideált büntető törvénykönyv könnyebb elfogadását (kevésbé idegen voltát) a transzlajtán koronatartományokban, így a szükebb értelemben vett Magyarországon is. ${ }^{19}$

A beépített rendelkezésekről alkotott ismertetésében, a bűntettek vonatkozásában (a legfontosabbak közül) Hugo Hoegel majd 120 különböző udvari és tartományi „decretumot” (Hof- und Landes-Decrete), rendeletet (Verordnung), legfelsőbb elhatározást (Allerhöchste Entschließung), pátenst (Patent) és törvényt (Gesetz) gyüjtött össze. Ami pedig a vétségek és kihágásokhoz kapcsolódó joganyagot illeti, ezek tételes felsorolását (hatalmas mennyiségük miatt) értelmetlen vállalkozásnak vélte és eleve meg sem kísérelte. ${ }^{20}$ Így az 1852 . évi kódexben éppen a vétségeket és kihágásokat tartalmazó rész jelentette a legnagyobb kihívást, elválaszthatatlan összefüggést alkotva az államreformokkal, valamint a közigazgatás és az igazságszolgáltatás szétválasztásával is, amely Magyarországon legkritikusabban éppen a vétségeket és kihágásokat elbíráló járásbíróságok szintjén exponálódott.

Hye kódexe tehát nem egy újonnan alkotott joganyagot foglalt magában. Ahogyan az I. Ferenc császár által bevezetett 1803. évi büntetötörvény az 1787. évi Sanctio Criminalis Josephina - amelyet egyébként rövid időre Magyarországon is bevezettek ${ }^{21}$ - számos jegyét magán hordozta, úgy az 1852. évi Strafgesetzbuch is tulajdonképpen az 1803-as revideált

17 Hye forrásai között főként német hercegségek büntetőtörvényei szerepeltek: Szász-Altenburg (1835), Württemberg (1839), Braunschweig (1840), Hannover (1843), Hessen (1844), Baden (1845), Nassau (1849), Weimar (1850), Porosz Királyság (1851), Szászország (1855), Oldenburg (1858) Bajorország (1861). A német büntetőtörvények mellett azonban Hye támaszkodott a francia Code Penalra, a toszkán (1856) és szardíniai (1859) kódexekre, a brit büntetőjogra, az orosz büntető törvénykönyvre (1845), valamint brémai (1861) és hamburgi (1862) tervezetekre is. AVA Nachlässe NA Hye 10.1.

18 Anton Hye Ritter von Glunek: Das österreichische Strafgesetz über Verbrechen, Vergehen und Uebertretungen, und die Pressordnung vom 27. Mai 1852. Wien, Verlag von Friedrich Manz, 1855. 8.

19 Hye (1855) i. m. 8-9.

20 Hugo Hoegel: Geschichte des Österreichischen Strafrechtes. Erstes Heft. Wien, Manzsche k. u. k. Hof-Verlags und Universitäts-Buchhandlung, 1904. 91-94.

${ }^{21}$ A Sanctio Criminalis Josephina bevezetéséről lásd Barna Attila: Kísérlet a magyar vármegyerendszer átalakítására. II. József közigazgatási és büntetőjogi reformjai a magyarországi vármegyékben. In Mezey Barna - Révész Tamás: Ünnepi tanulmányok Máthé Gábor 65. születésnapja tiszteletére. Budapest, Gondolat, 2006. 88-91. 
változatának volt tekinthető. Az eredeti 1803. évi Strafgesetz über Verbrechen und schwere Polizei-Uebertretungen alapvetően Franz Zeiller munkája, de más természetjogászok is jelentős hatást gyakoroltak rá, úgymint Karl Anton Martini, - a kódex II. részét összeállító - Joseph von Sonnenfels, ${ }^{22}$ Matthias von Haan, vagy Franz von Kees. ${ }^{23}$ Ezen kódex a dichotómikus felosztást követve a büntetésre méltó cselekményeket (strafbare Handlungen) büntettekre (Verbrechen) és súlyos rendőri kihágásokra (schwere Polizei-Übertretungen) osztotta fel.

\subsection{Az osztrák büntetöjog rendszere}

Az osztrák büntetőjog rendszerében a büntetendő cselekmények közül az 1803. évi törvénykönyv csak a büntettekre és a súlyos rendőri kihágásokra (ez utóbbiak lényegüket tekintve vétségek és kihágások) vonatkozóan rendelkezett, azonban természetesen léteztek a büntető törvénykönyv hatályán kívül eső csekélyebb kihágások is, ${ }^{24}$ amelyek lényegét jobban kifejezi az Übertretung szó expressis verbis jelentése, amely általában véve a jog áthágására utal.

Hye kódextervezetében a büntetésre méltó cselekményeket két fö kategóriába javasolta beosztani: egyrészt (A) a közvetlen és szántszándékos jogsértések (unmittelbare und absichtliche), másrészt (B) az egyéb jogsértések kategóriájába. Utóbbi kategóriát a büntettek komplementereként határozta meg egységes szankciórendszerrel és eljárási szabályokkal. Ezen magatartásokat tovább osztályozva megkülönböztette (B1) a csekély büntetteket; (B2) a közvetlen (de csupán) vétkes törvénysértéseket, azaz meghatározott jogszabályok áthágását (vétség); és végül (B3) a közvetett törvénysértéseket, amelyek esetében egy a törvénysértés prevencióját szolgáló rendőri norma megszegése történik. ${ }^{25}$

Vagyis a büntettek alapvetően a gonosz szándékot (dolus, böser Vorsatz) vagy károkozást, a vétségek a vétkességet (culpa, Fahrlässigkeit) feltételezték, míg a kihágások egy rendkívül heterogén csoportját adták a büntetendő cselekményeknek (strafbare Handlungen). Ami pedig a kihágásokat általában véve a normaszövegtől elvonatkoztatva illeti, Georg Lienbacher e deliktumokat az eljárásjog szempontjából rendszerezve három kategóriába sorolta. Ezek közül elsőként a bíróságok hatáskörébe tartozó kihágásokat nevezte meg (Gerichtsübertretungen). Másodikként a pénzügyi kihágásokat (Gefällsübertretungen) határozta meg, amelyeket külön törvényben meghatározott hivatalok vizsgáltak és büntettek. Végül harmadikként a legáltalánosabb kategóriát a rendőri kihágások (Polizeiübertretungen) alkották, ezek vizsgálata és büntetése a községi elöljárók

22 Az 1803. évi kódex 2. részét elkészítő Sonnenfelsre Martini mellett a kánonjogász Paul Joseph Riegger volt nagy hatással. Helga Strauss: Das STGB von Verbrechen und Schweren Polizeiübertretungen vom 3.9.1803. In Mezey Barna (szerk.): Rechtsgeschichtliche Abhandlungen Band 21. Strafrechtskodifikation im 18. und 19. Jahrhundert. Budapest, Mezey Barna, 1997. 63.

Olechowski (2010) i. m. 319-320.

Hye (1855) i. m. 50-51.

Uo. 57-58. 
(Gemeindevorstände), városi testületek (Magistrate), rendőri (Polizei-), közigazgatási (politische), bánya (Berg-) és más egyéb hatóságok (andere Behörden) hatáskörébe tartozott. $^{26}$

\subsection{Vétségek és kihágások}

$\mathrm{Az}$ 1852. évi törvény II. része együttesen tartalmazta a vétségeket és kihágásokat. Ezeknek három nemét különböztette meg a jogalkotó, aszerint, hogy a jogellenes magatartás a közbiztonság ellen, az egyén biztonsága ellen vagy a közerkölcsiség ellen irányult (275-277. \$\$). A kihágások természetük szerinti osztályozását érdemes röviden áttekintenünk a törvény szerkezetét alapul véve, e büntetendő cselekményeket együttesen a II. rész 9. fejezetében szabályozták:

- a közcsend és rend elleni vétségek és kihágások (278-310. \$\$);

- a közbiztonságra tartozó közintézetek és előintézkedések elleni kihágásokról (311330. $\$ \$)$

- a közhivatal kötelességei elleni kihágásokról (331-334. \$\$);

- az élet biztonsága elleni vétségek és kihágások (335-392. \$\$);

- az egészség elleni vétségek és kihágások (393-408. \$\$);

- a testi biztonságot sértő vagy fenyegető egyéb kihágások (409-433. \$\$);

- a tulajdon biztonsága elleni vétségek és kihágások (434-486. \$\$);

- a becsület biztonsága elleni vétségek és kihágások (487-499. \$\$);

- a közerkölcsiség elleni vétségek és kihágások (500-525. \$\$).

Az 1852. évi törvény szerkezetében tehát nem különülnek el a vétségek és a kihágások, sok tényállás szabályozásában az alakzat vagy a büntetendő cselekmény eredménye minősítette azt vétséggé vagy kihágássá. Olyan tényállások is előfordultak, amelyek esetében a kihágásban a vétség feltételesen foglaltatott benne. Erre példaként az élet biztonsága elleni vétségek és kihágások csoportja említhető (II. rész, VIII. fejezet), de a testi biztonságot sértő vagy fenyegető egyéb kihágások csoportjában (II. rész, X. fejezet) is találunk hasonló tényállásokat. Kihágásnak minősült például tárgyak ablakbóli kihajítása vagy azok nem megfelelő rögzítése, azonban ha a lehulló tárgy egy arra járó személy halálát okozta, a cselekmény (vagy mulasztás) vétségnek minősült (426. §.).

\subsection{Az OBTK büntetö rendszere és az eljárási szabályok}

A vétségek és kihágások esetében a törvénykönyv a büntetéseknek három fajtáját tartalmazta, a vagyonbüntetés és a szabadságvesztés mellett kiutasítást is, amely utóbbi

26 Georg Lienbacher: Das österreichische polizeiliche Strafrecht. Wien, Georg Lienbacher, 1873. 3. 
önmagában nem volt kiszabható. Ennek megfelelően a büntetési nemek a következők voltak (240. §): pénzbüntetés; portékák, áruk, eszközök elkobzása; jogok és jogosítványok elvesztése; fogság; testi fenyítés; kitiltás (valamely helyből, valamely koronaországból vagy az ausztriai császárság minden koronaországából, amely utóbbi csak külföldiekre szabható). ${ }^{27}$ A fogság büntetése súlyosbításként (253. §) böjttel, nehezebb munkával, kemény fekhely kirendelésével, magánfogsággal, sötét kamrábani magánelzárással és testi fenyítéssel volt súlyosbítható. ${ }^{28} \mathrm{Az}$ említetteken kívül a serdületlen (10-14 éves korig) által elkövetett kihágásképp minősülő bűntettek esetében külön őrizeti helyen elzárással (270. §), míg a tényállás szerint vétség és kihágást képező cselekmények atyai fenyítékkel büntettettek $(237 . \$) .^{29}$

A monarchia egész területére kiterjesztett büntető perrendtartás (Strafprozessordnung) 1853-ban történt bevezetéséig az örökös tartományokban az 1803. évi kódex alaki szabályai és az 1850. évi StPO ${ }^{30}$ volt érvényben, míg a szabadságharc során megszállt magyar területeken az 1849-ben ${ }^{31}$ és 1853-ban ideiglenes büntető perrendtartást ${ }^{32}$ vezették be. Az új (végleges) Strafprozessordnung a vétségek felett történő ítélkezést a társas - vagy I. osztályú - járásbíróságra (Bezirks-Collegialgericht) hagyta, míg a kihágások felett egyesbíróságok (Bezirksgericht) ítélkeztek, ${ }^{33}$ majd az 1854. évi szervezéseket követően a vegyes szolgabírói hivatalok ítéltek.

\section{AZ OBTK BEVEZETÉSE MAGYARORSZÁGON}

Ahogyan az Osztrák Császárság egészében (a Határőrvidéket nem számítva), úgy Magyarországon is 1852. szeptember 1-jével lépett hatályba az új büntető törvénykönyv, amelyre több tekintetben is égető szüksége volt a császári-királyi kormányzatnak.

Az egységesebb osztrák büntetőjogi szférához képest Magyarországon tradicionális büntetőjog volt érvényben a régi törvények és szokások szövevényes együttesével, ${ }^{34}$ amely az 1849 óta alkotott osztrák rendelkezésekkel is kiegészült. A szerteágazó feudális jellegü büntetőjog a Bach-kormányzat államszervező reformjait is hátráltatta. Az olmützi alkotmány (1849), majd a szilveszteri pátens (1851) rendelkezéseinek gyakorlati megvalósítása számos jogi és társadalmi problémát felvetett, illetve megvilágított. Egy-egy kérdéskör

27 Csatskó Imre: Az 1852-iki május 27-iki Austriai Birodalmi büntetőtörvény magyarázata. Pest, Geibel Ármin, 1853. 294-295.

Uo. 300.

29 Uo. 299.

30 Allgemeines Reichs-Gesetz- und Regierungsblatt für das Kaiserthum Österreich, (1850), 25.

31 Hirdetés a teljhatalmú polgári biztostól 1850. január 14-dikéről. II. Ideiglenes rendelet fenyitő biróságok illetősége és bűnvádi eljárás tárgyában. Magyarkoronaországot illető Országos Törvény-és Kormánylap, (1850), 2.

1853. julius 29. kelt császári nyiltparancs. Magyarországot illető Országos Kormánylap, 4. (1853), II./171.

33 Varga Endre: III. Az osztrák abszolutizmus korszaka (1849-1861). In Varga Endre (szerk.): A magyar bírósági szervezet és perjog története. Budapest, Müvelődési Minisztérium Levéltári Osztálya, 1961. 137-140.

34 Olechowski (2010) i. m. 324. 
vagy jogterület új szabályozásának bevezetése - úgy mint az ideiglenes, majd a végleges bírósági és közigazgatási szervezet felállítása, az úrbéri kérdés, az ősiség megszüntetése, az osztrák kódexek és perrendtartások bevezetése stb. - többnyire más kérdések jogi rendezésétől volt függőben, gyakran újabb rendezendő szervezési kihívásokat felszínre hozva. Így az egymásba nyúló ideiglenes rendelkezések, részleges jogalkotási folyamatok, vagy éppen az átfogó szabályok hosszasan húzódó kidolgozása az osztrák kormányzat szervezőmunkája során számos nehézséget okozott.

Az Olmützi Alkotmány által előirányzott alapelvek az ideiglenes rendezés során a gyakorlatban nem tudtak kiteljesedni. Azonban szervezeti értelemben a klasszikus jogállam egyik fundamentumát - még ha rövid időre is - mégis megvalósította a Bach-kormányzat, amely a közigazgatást az igazságszolgáltatástól a legalsóbb járási szintig szétválasztotta. A helyzetet nehezítette a testi fenyítés megszüntetése is, ami aztán ahhoz is vezetett, hogy a politikai hatóságok bírói hatalmuktól megfosztva képtelenek voltak rendet tartani. A pozsonyi kerület föispánja Forgách Antal 1851-ben jelentette a Helytartóságnak, hogy a politikai szolgabírói hivatalok botoztatni kezdtek. Majd körutazását követően kétségbeesetten számolt be róla, hogy a botbüntetés megvonása a politikai hatóságoktól végzetes következményekkel járt, mivel a csekély pénz- és fogságbüntetéseknek visszatartó ereje nincs. A kormány álláspontja hosszabb távon oda vezet, hogy a kormányrendeleteket csak katonai karhatalommal lehet majd végrehajtatni. ${ }^{35}$

A másik ellenmondást éppen az előremutató büntetőjogi törekvések jelentették, úgy mint a szabadságvesztés-büntetések előtérbe helyezése (a testi fenyítéssel szemben), ami a börtönviszonyok rendezését is szükségessé tette. A budai helytartóság sürgette a bíróságok végleges rendezését, egyúttal felhívta a figyelmet a börtönügy tarthatatlan állapotára. ${ }^{36}$ Albrecht kormányzóvá kinevezésekor (1851. november) Geringer, mint a Helytartóság addigi vezetője részletes és átfogó jelentésben számolt be a főhercegnek. A jelentés köznyugalom és közbiztonságról szóló IV. fejezetében Geringer a börtönügy szabályozása mellett felhívja a figyelmet célszerüen kialakított dologházak (Arbeitshäuser) és javítóintézetek (Correktionsanstalten) fenyegetö hiányára is. Geringer az elhanyagolt börtönökben büntetésüket töltő elítéltek állapotát siralmasnak nevezi, aminek következtében az intézetekben rendszeres személyes ellenőrzéseket fognak tartani. ${ }^{37}$

Egy a büntető törvénykönyv bevezetését közvetlenül megelőző ügy a magyar büntetőnormák bizonytalanságaira is rámutatott. Az 1849-ben bevezetett alkotmányos vívmányok ugyanis büntetőjogi garanciák nélkül korlátozottan érvényesültek. 1851-ben egy állásából elbocsátott görög-keleti vallású tanár, Basil Popovics a cs. k. Soproni Kerületi Tanhatóságnál vesztegetéssel próbálta elérni visszahelyeztetését. Mivel a vesztegetési kísérletet a hatályos törvényekben még nem rögzítették (a hivatalnokok számára az ajándékok elfogadásának tilalmát is csupán Geringer Károly egyik rendeletében említették), ${ }^{38}$ törvényben

\footnotetext{
Sashegyi Oszkár: Az abszolutizmuskori levéltár. Budapest, Akadémiai Kiadó, 1965. 55-58.

Berzeviczy Albert: Az absolutismus kora Magyarországon 1849-1865. I. kötet. Budapest, Franklin, 1922. 323.

MNL OL D39. 1.d. 149. ügydarab.

Magyarországot illető Országos Kormánylap, (1852), 37.
} 
meghatározott tényállás hiányában a cs. k. Pécsi Megyei Törvényszék (k.k. Landesgericht zu Fünfkirchen) felmentette Popovicsot.

A kényes ügy hatalmas visszhangot vert, egészen 1852 nyaráig húzódott (amikor az új büntető törvénykönyv már közzététetett, de hatályba még nem lépett), és mármár jogelméleti vitákat kavart a magyarországi hatóságok, Geringer Károly helytartó és Krauss igazságügy-miniszter között. A soproni kormánykerület főispánja, Hauer báró hevesen támadta a pécsi törvényszék felmentő ítéletét és a soproni kerületi föügyész, Hengelmüller báró passzivitását is. Hauer Albrecht főherceghez intézett 1852. május 17-i feliratában az ítéletet rendkívül rossz precedensnek tartja, amely a végleges rendezés (definitivum) szervezési munkálatainak kellős közepén aláássa a hivatali ethoszt, és megnehezíti a - magyar területeken oly mélyen gyökeredző - vesztegetés gyakorlatának felszámolását. ${ }^{39}$ Végül Hauer beletörődött a közben jogerőssé vált ítélet megmásíthatatlanságába, Krauss igazságügy-miniszter reményét fejezte ki, hogy az új büntető törvénykönyv bevezetése elejét veszi a hasonló problémáknak. ${ }^{40}$

Függetlenül Hye reformmunkálataitól, Magyarországon égető szükség volt egy büntetőkódex megalkotására, a magyar kodifikációs törekvések története ekkor már hosszú időre nyúlt vissza, ${ }^{41}$ és az osztrák császári királyi kormányzat államszervező tevékenysége során is világossá vált. A bécsi minisztertanács és a birodalmi tanács a magyar koronatartományban felállított ideiglenes osztrák hivatalok szervezőmunkája révén figyelemmel kísérte a magyarországi provizorikus államszervezés nehézségeit, éppen ezekre a fejleményekre tekintettel volt kénytelen Hye 1852-ben egy kevésbé ambíciózus kódexet összeállítani. A Strafgesetz fogadtatása több szempontból is kedvezőtlen volt. Már az 1803. évi eredeti kódex is hamar reformokra szorult. Zeiller utólag maga is kritikusan viszonyult a kódexhez, hangsúlyozta az általános megelőzés (Generalprevention) fontosságát, a polgári szabadságjogok lehető legkisebb korlátozásával. ${ }^{42}$ Az OBTK még kevésbé tűnt előremutatónak, különösen a Deák-féle 1843-as javaslathoz képest. Ennek ellenére mégsem csupán dogmatikai, sokkal inkább érzelmi, az 1848-49-es eseményekre visszavezethető okai voltak az osztrák kódex 1861-ben történt kivezetésének, ugyanis Pauler az 1861-ben fennálló bírói gyakorlatot adaptálta Büntetőjogtanában. Csatskó tervezete, amely a Deákféle 1843-as javaslatot vette alapul, nem emelkedett törvényerőre, míg a Csemegi-féle kódexek, összességében sokkal közelebb álltak két (később törvényerőre nem emelkedett) osztrák javaslat, az 1863. évi osztrák büntető törvénykönyv és a 1870. évi Polizeistrafgesetz szerkezetéhez.

MNL OL D46 1852/1877. Hauer Albrechtnek. Sopron, 1852.05.17.

MNL OL D46 1852/1877. Krauss Albrechtnek. Bécs, 1852.06.19.

Mezey Barna: Über die Rolle der Kodifikationsbewegung in der Ungarischen Rechtsgeschichte. Rechtsgeschitliche Abhandlungen 21. Budapest, 1997. 90-94.

42 Christian Neschwara: Franz Zeiller und das Strafrecht: Seine Ambitionen zur Verbesserung des österreichischen Strafgesetzes von 1803. Revista Chilena de Historia del Derecho, 22. (2010), 366-367. 
Az 1852. évi osztrák büntető törvénykönyv összességében nem volt modernnek mondható, mégis számos pozitív hatását bizonyítja Pauler adaptációja is. A kódex a törvények és az írott jog primátusának szemléletét erősítette, keretbe fogta a bírói praxist, erősítette a büntetőjogi szakirodalmat ${ }^{43}$ előtérbe helyezte a szabadságvesztés-büntetést, illetve trichotomikus rendszert alakított ki.

43 Mezey Barna: A büntetőjogi kodifikáció kérdése a monarchikus diktatúrák korában. In Béli Gábor - Korsósné Delacasse Krisztina - Herger Csabáné (szerk.): Ut juris ordo exigit. Ünnepi tanulmányok Kajtár István 65. születésnapja tiszteletére. Pécs, Publikon, 2016. 186. 


\section{FELHASZNÁLT IRODALOM}

1. 1853. julius 29. kelt császári nyiltparancs. Magyarországot illető Országos Kormánylap, 4. (1853), II./171.

2. Barna Attila: Kísérlet a magyar vármegyerendszer átalakítására. II. József közigazgatási és büntetőjogi reformjai a magyarországi vármegyékben. In Mezey Barna - Révész Tamás: Ünnepi tanulmányok Máthé Gábor 65. születésnapja tiszteletére. Budapest, Gondolat, 2006. 77-96.

3. Bernatzik, Edmund: Die österreichischen Verfassungsgesetze mit Erläuterungen. Wien, Manzsche k. u. k. Hof-Verlags und Universitäts-Buchhandlung, 1911.

4. Berzeviczy Albert: Az absolutismus kora Magyarországon 1849-1865. I. kötet. Budapest, Franklin, 1922.

5. Csatskó Imre: Az 1852-iki május 27-iki Austriai Birodalmi büntetötörvény magyarázata. Pest, Geibel Ármin, 1853.

6. Degré Alajos: A magyar büntetöjoggyakorlat általános jellemzése (1861-1867). Jogász szövetségi értekezések II. Budapest, 1979.

7. Finkey Ferenc: A magyar büntetöjog tankönyve. Budapest, Grill Károly, 1914.

8. Heka László: Horvát alkotmány-és jogtörténet. II. rész (1848-tól 1918-ig). Szeged, JATE Press, 2004.

9. Hirdetés a teljhatalmú polgári biztostól 1850. január 14-dikéről. II. Ideiglenes rendelet fenyitő biróságok illetősége és bủnvádi eljárás tárgyában. Magyarkoronaországot illető Országos Törvény- és Kormánylap, (1850), 2.

10. Hoegel, Hugo: Geschichte des Österreichischen Strafrechtes. Erstes Heft. Wien, Manzsche k. u. k. Hof-Verlags und Universitäts-Buchhandlung, 1904.

11. Hye Ritter von Glunek, Anton: Das österreichische Strafgesetz über Verbrechen, Vergehen und Uebertretungen, und die Pressordnung vom 27. Mai 1852. Wien, Verlag von Friedrich Manz, 1855.

12. Ideiglenes Törvénykezési Szabályok. Pest, Landerer és Heckenast, 1861.

13. Képessy Imre: Az osztrák büntetőjog hatása a magyar büntetőjogi kodifikációra. In Fazekas Marianna (szerk.): Jogi tanulmányok 2018. Budapest, ELTE Állam- és Jogtudományi Kar Âllam- és Jogtudományi Doktori Iskola, 2018. 260-270.

14. Lienbacher, Georg: Das österreichische polizeiliche Strafrecht. Wien, Georg Lienbacher, 1873.

15. Magyarországot illető Országos Kormánylap, (1852), 37.

16. Máthé Gábor: A kihágás intézménye I. Állam és Igazgatás, 30. (1980a), 8. 673-683.

17. Máthé Gábor: A kihágás intézménye II. Állam és Igazgatás, 30. (1980b), 9. 804-818.

18. Mezey Barna: A büntetöjogi kodifikációk kérdése a monarchikus diktatúrák korában. In Béli Gábor - Korsósné Delacasse Krisztina - Herger Csabáné (szerk.): Ut juris ordo exigit. Ünnepi tanulmányok Kajtár István 65. születésnapja tiszteletére. Pécs, Publikon, 2016.

19. Mezey Barna: „A föltétlen igazság és a társadalom fenntartásának érdeke”. Az első magyar büntetötörvénykönyv. In Horváth Attila (szerk.): Tanulmányok a Csemegi- 
kódex megalkotásának 140. évfordulója tiszteletére. Budapest, Dialóg Campus, 2020. $39-46$.

20. Mezey Barna: Über die Rolle der Kodifikationsbewegung in der Ungarischen Rechtsgeschichte. Rechtsgeschitliche Abhandlungen 21. Budapest, 1997.

21. Neschwara, Christian: Franz Zeiller und das Strafrecht: Seine Ambitionen zur Verbesserung des österreichischen Strafgesetzes von 1803. Revista Chilena de Historia del Derecho, 22. (2010), 363-388.

22. Olechowski, Thomas: Zur Entstehung des österreichischen Strafgesetzes 1852. In Thomas Olechowski - Chirstian Neschwara - Alina Lengauer (szerk.): Grundlagen der österreichischen Rechtskultur. Festschrift für Werner Ogris zum 75. Geburtstag. Böhlau, Wien, 2010.319-341. DOI: https://doi.org/10.7767/boehlau.9783205790907.319

23. Österreichisches Biographisches Lexikon 1815-1950, Bd. 3. Bécs, VÖAW, 1961.

24. Pauler Tivadar: Büntetőjogtan. Pest, Pfeiffer Ferdinánd, 1864-1865. I.-II. k.

25. Ráth György (szerk.): Az országbirói értekezlet a törvénykezés tárgyában. Pest, Landerer és Heckenast, 1861.

26. Sashegyi Oszkár: Az abszolutizmuskori levéltár. Budapest, Akadémiai Kiadó, 1965.

27. Strauss, Helga: Das STGB von Verbrechen und Schweren Polizeiübertretungen vom 3.9.1803. In Mezey Barna (szerk.): Rechtsgeschichtliche Abhandlungen Band 21. Strafrechtskodifikation im 18. und 19. Jahrhundert. Budapest, Mezey Barna, 1997.

28. Varga Endre: III. Az osztrák abszolutizmus korszaka (1849-1861). In Varga Endre (szerk.): A magyar bírósági szervezet és perjog története. Budapest, Művelődési Minisztérium Levéltári Osztálya, 1961. 33-150.

29. Veress Emőd (szerk.): Erdély jogtörténete. Kolozsvár, Forum Iuris, 2018.

Levéltári források

1. MNL OL D46 - Magyar Nemzeti Levéltár Országos Levéltára, Abszolutizmuskori Levéltár, Katonai és Polgári Kormányzóság (Militär- und Civil-Gouvernement), Polgári Ügyosztály (Civil Section)

2. AVA Nachlässe AN Hye 10. - Österreichisches Staatsarchiv, Allgemeine Verwaltungsarchiv, Nachlässe, Anton Hye, Karton 10. 
Szabó Mátyás egyetemi tanársegéd, a magyar alkotmány- és közigazgatástörténet oktatásával és kutatásával foglalkozik. Tanulmányait a Nemzeti Közszolgálati Egyetemen végezte, 2016-ban igazgatásszervező, majd 2018-ban nemzetközi közszolgálati szakértő képesítést szerzett. Jelenleg doktori tanulmányait a Közigazgatás-tudományi Doktori Iskola Állam- és közigazgatás-történet kutatási területén folytatja, amelynek keretében az Osztrák-Magyar Monarchia közös külügyminisztériumának szervezetét és működését kutatja. 2017-ben a XXXIII. Országos Tudományos Diákköri Konferencián I., míg 2019-ben III. helyezést ért el, ugyanebben az évben Pro Scientia Aranyéremben részesült. 